\title{
PENGARUH STRATEGI PEMBELAJARAN DAN TIPE KEPRIBADIAN TERHADAP HASIL BELAJAR EKONOMI
}

\author{
Ruth Melarty Simarmata ${ }^{1}$ Efendi Napitupulu ${ }^{2}$, Abdul Hasan Saragih ${ }^{3}$ \\ ${ }^{1}$ Sekolah Menengah Atas Negeri 1 Siantar, Simalungun, \\ ${ }^{2,3}$ Pascasarjana Universitas Negeri Medan \\ ruthmelarty@ymail.com
}

\begin{abstract}
Abstrak: Penelitian ini bertujuan untuk: (1) Mengetahui perbedaan hasil belajar Ekonomi siswa yang dibelajarkan dengan strategi pembelajaran kooperatif tipe STAD dengan strategi pembelajaran ekspositori. (2) Mengetahui perbedaan hasil belajar Ekonomi siswa yang memiliki tipe kepribadian eksovert dan tipe kepribadian introvert, dan (3) Mengetahui interaksi antara strategi pembelajaran dan tipe kepribadian siswa terhadap hasil belajar Ekonomi. Penelitian ini merupakan penelitian kuasi eksperimen. Populasi penelitian 267 orang yang berasal dari 6 kelas. sampel seluruhnya terdiri dari dua kelas dengan menggunakan cluster random sampling. Teknik analisis data penelitian dengan statistik deskriptif menyajikan data statistik inferensial untuk menguji hipotesis penelitian. Hipotesis penelitian diuji dengan menggunakan Anava 2 jalur yang sebelumnya, terlebih dahulu dilakukan uji persyaratan analisis data yaitu uji normalitas data dengan uji Lilliefors dan uji homogenitas varians dengan uji Fisher dan uji Bartlett dan dilanjutkan dengan uji Scheffe. Hasil analisis data diperoleh; (1) hasil belajar Ekonomi siswa yang dibelajarkan dengan strategi pembelajaran kooperatif tipe STAD lebih tinggi daripada yang dibelajarkan dengan strategi pembelajaran ekspositori. (2) hasil belajar Ekonomi siswa yang memiliki tipe kepribadian ekstrovert lebih tinggi daripada tipe kepribadian introvert, dan (3) terdapat interaksi antara strategi pembelajaran dan tipe kepribadian siswa dalam mempengaruhi hasil belajar Ekonomi. Hasil penelitian menunjukkan bahwa untuk meningkatkan hasil belajar Ekonomi, strategi pembelajaran kooperatif tipe STAD tepat digunakan bagi siswa yang memiliki tipe kepribadian ekstrovert. Siswa yang memiliki tipe kepribadian introvert lebih efektif dibelajarkan dengan strategi pembelajaran ekspositori.
\end{abstract}

Kata Kunci: strategi pembelajaran, kooperatif tipe STAD, ekspositori, kepribadian, ekonomi

Abstract: This study aims to: (1) Know the differences in students' economic learning outcomes taught by STAD type cooperative learning strategies and expository learning strategies. (2) Knowing the differences in students' economic learning outcomes that have ecsovert personality types and introverted personality types, and (3) Knowing the interaction between learning strategies and student personality types on economic learning outcomes. This research is a quasi-experimental research. The study population was 267 people from 6 classes. The sample consists entirely of two classes using cluster random sampling. Research data analysis techniques with descriptive statistics present inferential statistical data to test research hypotheses. The research hypothesis was tested using the Anava 2 path previously, the data analysis requirements were tested first, namely the data normality test with the Lilliefors test and the variance homogeneity test with the Fisher and Bartlett test and continued with the Scheffe test. The results of data analysis are obtained; (1) Economic learning outcomes of students who are taught with STAD type cooperative learning strategies are higher than those taught by expository learning strategies. (2) Economic learning outcomes of students who have extroverted personality types are higher than introverted personality types, and (3) there is an interaction between learning strategies and student personality types in influencing Economic learning outcomes. The results showed that to improve economic learning outcomes, STAD type cooperative learning strategies are appropriate for students who have extroverted personality types. Students who have introverted personality types are more effectively taught with expository learning strategies.

Keywords: learning strategies, cooperative STAD type, expository, personality, economics

\section{PENDAHULUAN}

Mata Pelajaran Ekonomi diberikan sebagai mata pelajaran tersendiri pada tingkat SMA. Ekonomi merupakan ilmu tentang perilaku dan tindakan manusia untuk memenuhi kebutuhan hidupnya yang bervariasi, dan berkembang dengan sumber daya yang ada melalui pilihan-pilihan kegiatan produksi, kosumsi, dan distribusi. Luasnya ilmu ekonomi dan terbatasnya waktu yang tersedia membuat standar kompetensi dan kompetensi dasar dibatasi dan fokus pada fenomena ekonomi yang ada di sekitar siswa, sehingga siswa dapat merekam peristiwa ekonomi yang terjadi di 
sekitar lingkungannya dan mengambil manfaat untuk kehidupan yang lebih baik. Adapun ruang lingkup dari mata pelajaran ekonomi meliputi aspek-aspek: (1) Perekonomian; (2) Ketergantungan; (3) Spesialisasi dan Pembagian Kerja; (4) Perkoperasian; (5) Kewirausahaan; dan (6) Akuntansi dan Manajemen. Keseluruh aspek-aspek tersebut diselenggarakan dalam proses belajar mengajar.

Berbagai strategi pembelajaran telah diperkenalkan oleh para ahli dalam rangka mencapai tujuan pembelajaran seperti yang dikemukakan oleh Sanjaya (2007:177) yaitu strategi pembelajaran ekspositori, strategi pembelajaran inquiry, strategi pembelajaran berbasis masalah, strategi pembelajaran peningkatan kemampuan berpikir, strategi pembelajaran kooperatif, strategi pembelajaran kontekstual CTL dan strategi pembelajaran afektif. Dari keseluruhan strategi pembelajaran tersebut, tidak ada strategi pembelajaran yang dianggap lebih baik dibandingkan dengan strategi pembelajaran yang lain. Baik tidaknya suatu strategi pembelajaran bisa dilihat dari efektif tidaknya strategi tersebut dalam mencapai tujuan pembelajaran yang telah ditentukan. Dengan demikian, pertimbangan pertama dalam penggunaan strategi pembelajaran yang akan diterapkan di kelas adalah tujuan apa yang harus dicapai.

Strategi Pembelajaran Kooperatif Tipe

STAD merupakan strategi pembelajaran kooperatif yang sederhana, mudah diterapkan dalam pembelajaran pada umumnya dan cocok digunakan oleh guru yang baru mulai menggunakan pembelajaran kooperatif. Strategi STAD dalam aplikasi sintaksnya memiliki komponen presentasi kelas, kerja kelompok, kuis, pengembangan individu, dan rekognisi tim (Slavin, 1995:71). Strategi pembelajaran ini mengacu pada pembelajaran kelompok yaitu guru menyajikan informasi akademik baru kepada siswa dengan menggunakan persentase verbal/teks. Anggota tim menggunakan lembar kegiatan/perangkat pembelajaran yang lain untuk memahami bahan pelajaran melalui tutorial, kuis, dan diskusi. Oleh karena itu, untuk mencapai tujuan kelompok setiap anggota kelompok harus membantu teman kelompoknya yang dapat mendorong kelompok itu mencapai tujuannya. Sehingga, seluruh siswa dapat terlibat aktif dalam pembelajaran dan dapat berdampak pada kualitas interaksi dan komunikasi antar siswa sebab siswa di dalam kelompoknya saling membantu temannya yang mengalami kesulitan memahami pelajaran dalam upaya mencapai hasil belajar yang memuaskan pada setiap kelompok. Strategi pembelajaran kooperatif tipe STAD ini mampu melatih siswa dalam menumbuhkan kemampuan berpikir secara mandiri.

\section{Hakikat Belajar dan Hasil Belajar Ekonomi}

Slameto (2003:2) mengemukakan belajar adalah suatu proses usaha yang dilakukan seseorang untuk memperoleh perubahan tingkah laku yang baru secara keseluruhan, sebagai hasil pengalamannya sendiri dalam interaksi dengan lingkungannya. Perubahan itu bersifat relatif konstan dan berbekas. Hal tersebut senada dengan yang dikemukakan oleh Hamalik (2003:154) belajar adalah perubahan tingkah laku yang relatif mantap berkat latihan dan pengalaman. Dalam The Guidance of Learning Activities Burton (dalam Siregar \& Nara, 2010:4) mengemukakan Belajar adalah proses perubahan tingkah laku pada diri individu karena adanya interaksi antara individu dengan individu dan individu dengan lingkungannya sehingga mereka lebih mampu berinteraksi dengan lingkungannya.

Suryabrata (2002:234) menjelaskan bahwa belajar merupakan suatu proses perubahan tingkah laku sebagai suatu hasil interaksi dengan lingkungannya dalam memenuhi kebutuhan dengan ciri-ciri; (1) perubahan terjadi secara sadar, (2) perubahan dalam belajar terjadi bersifat kontinyu dan fungsional, (3) perubahan dalam belajar terjadi bersifat positif dan aktif artinya perubahan itu senantiasa bertambah dan tertuju untuk memperoleh sesuatu yang lebih baik dari sebelumnya, (4) perubahan dalam belajar bukan bersifat sementara, tetapi bersifat permanen, (5) perubahan dalam belajar bertujuan terarah, dan (6) perubahan dalam belajar mencakup seluruh aspek tingkah laku. Selanjutnya Suryabrata (2002:232) menjelaskan bahwa di dalam belajar terdapat beberapa hal yang pokok untuk dipahami yaitu: (1) belajar membawa perubahan dalam arti behavioural change (perubahan tingkah laku), aktual maupun potensial, (2) perubahan tersebut pada pokoknya adalah didapatkannya kecakapan baru, dan (3) perubahan itu terjadi karena usaha-usaha atau dengan sengaja. 


\section{Hakikat Hasil Belajar Ekonomi}

Keberhasilan seseorang dalam proses pembelajaran dapat di lihat dari hasil belajar yang diperoleh. Hasil belajar adalah kemampuan-kemampuan yang dimiliki siswa setelah ia menerima pengalaman belajarnya. Kemp (1994:141) menjelaskan hasil belajar akan terlihat dengan adanya tingkah perilaku baru pada tingkat kemampuan berpikir atau kemampuan jasmaniah. Sedangkan Gagne \& Briggs (1979:49) mengemukakan bahwa hasil belajar dapat dikelompokkan ke dalam lima kategori yaitu keterampilan intelektual, strategi kognitif, informasi verbal, kemampuan motorik dan sikap.

Dimyati \& Moedjiono (2002;36) mengemukakan hasil belajar adalah hasil yang ditunjukkan dari suatu interaksi tindak belajar dan biasanya di tunjukkan dengan nilai tes yang diberikan guru. Sedangkan Hamalik (2006:30) mengemukakan hasil belajar adalah bila seseorang telah belajar akan terjadi perubahan tingkah laku pada orang tersebut, misalnya dari tidak tahu menjadi tahu, dan dari tidak mengerti menjadi mengerti.

Romiszowski (1981:217) menyatakan bahwa hasil belajar diperoleh dalam bentuk pengetahuan dan keterampilan. Pengetahuan dikelompokkan pada empat kategori yaitu: (1) fakta, merupakan pengetahuan tentang obyek nyata, asosiasi dari kenyataan, dan informasi verbal dari suatu objek, peristiwa atau manusia, (2) konsep, merupakan pengetahuan tentang seperangkat objek konkret atau definisi, (3) prosedur, merupakan pengetahuan tentang tindakan demi tindakan yang bersifat linier dalam mencapai suatu tujuan, dan (4) prinsip, merupakan pernyataan mengenai hubungan dari dua konsep atau lebih. Sedangkan hasil belajar dalam bentuk keterampilan juga dikelompokkan dalam empat kategori yaitu : (a) keterampilan kognitif, merupakan keterampilan seseorang dalam menggunakan pikiran untuk mengambil keputusan atau memecahkan masalah, (b) acting, yaitu keterampilan fisik atau teknik seperti olahraga atau terampil dalam mengerjakan sesuatu, dan (c) reaksi, merupakan keterampilan bereaksi terhadap suatu situasi dalam artian nilai-nilai emosi dan perasaan dengan orang lain untuk mencapai suatu tujuan seperti komunikasi, persuasif, dan pendidikan.

Reigeluth (1983:20) secara umum mengkategorikan tiga indikator keberhasilan belajar siswa yaitu: (1) efektivitas pembelajaran yang biasanya di ukur dari tingkat keberhasilan siswa dari berbagai sudut, (2) efisiensi pembelajaran yang biasanya diukur dari waktu dan pembiayaan pembelajaran, dan (3) daya tarik pembelajaran yang selalu diukur dari tendensi siswa ingin belajar terus menerus. Menurut Gagne (1985:40) hasil belajar dapat diartikan sebagai kapasitas atau kemampuan yang dapat diperoleh dari proses belajar yang dapat dikelompokkan kedalam lima kategori yaitu; (1) kognitif, (2) informasi verbal, (3) strategi kognitif, (4) keterampilan motorik, dan (5) sikap. Sedangkan Bloom (1976:201) menggunakan educational objective untuk hasil belajar, yang terbagi atas aspek kognitif domain, afektif domain, dan psikomotor domain.

Mata Pelajaran Ekonomi diberikan pada tingkat pendidikan dasar sebagai bagian integral dari IPS. Pada tingkat pendidikan menengah, ekonomi diberikan sebagai mata pelajaran tersendiri. Berkaitan dengan bidang studi ekonomi untuk tingkat SMA, Departemen Pendidikan Nasional (2006) menjelaskan bahwa mata pelajaran ekonomi diberikan untuk tingkat SMA bertujuan agar siswa memiliki kemampuan sebagai berikut; (1) memahami sejumlah konsep ekonomi untuk mengkaitkan peristiwa dan masalah ekonomi dengan kehidupan sehari-hari, terutama yang terjadi di lingkungan individu, rumah tangga, masyarakat, dan negara, (2) menampilkan sikap ingin tahu terhadap sejumlah konsep ekonomi yang diperlukan untuk mendalami ilmu ekonomi, (3) membentuk sikap bijak, rasional dan bertanggung jawab dengan memiliki pengetahuan dan keterampilan ilmu ekonomi, manajemen, dan akuntansi yang bermanfaat bagi diri sendiri, rumah tangga, masyarakat, dan negara, (4) membuat keputusan yang bertanggung jawab mengenai nilai-nilai sosial ekonomi dalam masyarakat yang majemuk, baik dalam skala nasional maupun internasional.

\section{Hakikat Strategi Pembelajaran}

$\begin{array}{clr}\text { Gerlach \& Ely } & (1980: 15) \\ \text { mengemukakan } & \text { strategi } & \text { pembelajaran }\end{array}$ merupakan cara-cara yang dipilih untuk menyampaikan metode pembelajaran dalam lingkungan pembelajaran tertentu. selanjutnya mereka menjabarkan bahwa strategi pembelajaran dimaksud meliputi sifat, lingkup, dan urutan kegiatan pembelajaran yang dapat memberikan pengalaman belajar kepada peserta didik. Sedangkan Kemp (1995:54) 
menjelaskan bahwa strategi pembelajaran adalah suatu kegiatan pembelajaran yang harus dikerjakan guru dan siswa agar tujuan pembelajaran dapat dicapai secara efektif dan efisien. Kemudian Dick \& Carey (2015:30) juga menyebutkan bahwa strategi pembelajaran adalah suatu set materi dan prosedur pembelajaran yang digunakan secara bersamasama untuk mencapai hasil belajar siswa. Sedangkan Sanjaya (2007:126) mengemukakan strategi pembelajaran adalah perencanaan yang berisi tentang rangkaian kegiatan yang didesain untuk mencapai tujuan pendidikan tertentu

Dick \& Carey (2015:73) menambahkan bahwa strategi pembelajaran memuat lima komponen utama yaitu: (1) aktivitas pembelajaran pendahuluan, (2) penyampaian informasi, (3) partisipasi peserta didik, (4) tes, (5) kegiatan lanjutan. Selanjutnya dalam strategi pembelajaran terkandung empat komponen sebagaimana yang dijelaskan Suparman (2001:151) yaitu; (1) urutan kegiatan pembelajaran, yaitu urutan kegiatan pengajar dalam menyampaikan isi pelajaran kepada siswa, (2) metode pembelajaran, yaitu cara pengajar mengorganisasikan materi pelajaran dan siswa agar terjadi proses belajar secara efektif dan efisien, (3) media pembelajaran, yaitu peralatan dan bahan pembelajaran yang digunakan pengajar dan siswa dalam kegiatan pembelajaran, dan (4) waktu yang digunakan oleh pengajar dan siswa dalam menyelesaikan setiap langkah dalam kegiatan siswa.

Selanjutnya Reigeluth (1983:57) membagi strategi pembelajaran menjadi tiga bagian yaitu: (1) strategi pengorganisasian pembelajaran yang merupakan metode untuk mengorganisasikan isi dari mata pelajaran yang akan diajarkan. (2) strategi penyampaian pembelajaran yaitu berupa metode untuk menyampaikan mata pelajaran dan (3) strategi pengelolaan pembelajaran yaitu berupa metode untuk mengambil keputusan berkaitan dengan komponen-komponen strategi pengorganisasian dan strategi penyampaian. Sedangkan dalam penelitian ini strategi pembelajaran yang dimaksud adalah strategi pengorganisasian pembelajaran dalam mengorganisasi isi mata pelajaran ekonomi, terbagi dalam dua strategi pembelajaran yaitu strategi pembelajaran kooperatif tipe STAD dan strategi pembelajaran ekspositori.

\section{Strategi Pembelajaran Kooperatif}

Pembelajaran kooperatif merupakan salah satu pembelajaran yang dikembangkan dari teori konstruktivisme karena mengembangkan struktur kognitif untuk membangun pengetahuan sendiri melalui berpikir rasional (Rustaman et al., 2003: 206). Filsafat konstruktivisme beranggapan bahwa pengetahuan adalah hasil konstruksi manusia melalui interaksi dengan objek, fenomena pengalaman dan lingkungan mereka. Hal ini sesuai dengan pendapat Poedjiadi (2005:70) bahwa konstruktivisme bertitik tolak dari pembentukan pengetahuan, dan rekonstruksi pengetahuan adalah mengubah pengetahuan yang dimiliki seseorang yang telah dibangun atau dikonstruk sebelumnya dan perubahan itu sebagai akibat dari interaksi dengan lingkungannya.

Kagan (2000:1) mengemukakan pembelajaran kooperatif adalah suatu istilah yang digunakan dalam prosedur pembelajaran interaktif, dimana siswa belajar bersama-sama dalam kelompok-kelompok kecil untuk memecahkan masalah. Setiap siswa tidak hanya menyelesaikan tugas individunya, tetapi juga berkewajiban membantu tugas teman kelompoknya, sampai semua anggota kelompok memahami suatu konsep.

Johnson $\&$ Johnson $\quad(2001: 1)$
mengemukakan definisi pembelajaran kooperatif bahwa pembelajaran kooperatif merupakan relasi peserta didik dalam kelompok yang memerlukan ketergantungan positif, tanggung jawab individu, keterampilan interpersonal, interaksi tatap muka, dan proses kelompok. Ketergantungan positif berkaitan dengan tugas yang hanya dapat dikerjakan dan diselesaikan bersama. Tanggung jawab individu berkaitan dengan motivasi individu untuk belajar dan membantu teman kelompoknya, sehingga setiap individu mempunyai kesempatan sama memberikan kontribusi dalam keberhasilan kelompok. Kterampilan interpersonal berkaitan dengan komunikasi, rasa saling percaya, kepemimpinan, pengambilan keputusan, dan pemecahan konflik di antara anggota kelompok. Interaksi tatap muka dan proses kelompok berkaitan dengan bagaimana anggota bekerjasama melaksanakan fungsi kelompok, sehingga kelompok mereka sukses.

Kauchak (1998:234) mengemukakan pembelajaran kooperatif merupakan kumpulan strategi pembelajaran yang digunakan untuk 
membantu siswa menemukan ilmu pengetahuan yang spesifik dan memberikan masukan antar personal dalam group. Sedangkan Lie (2008:18) mengemukakan cooperative learning dengan istilah pembelajaran gotong royong, sistem pembelajaran yang memberikan kesempatan kepada siswa bekerja sama dengan siswa lain dalam tugas-tugas yang terstruktur. Menurut Slavin (dalam Isjoni, 2009:15) pembelajaran kooperatif adalah suatu model pembelajaran dimana siswa belajar dan bekerja dalam kelompok-kelompok kecil secara kolaboratif yang anggotanya 5 orang dengan struktur kelompok yang heterogen.

Belajar kooperatif bukan lebih dari sekedar belajar kelompok atau kerja kelompok karena dalam belajar kooperatif ada struktur dorongan atau tugas yang bersifat kooperatif sehingga memungkinkan terjadinya interaksi secara terbuka dan hubungan yang bersifat interdepedensi. Menurut Isjoni (2009:27) pembelajaran kooperatif memiliki ciri-ciri sebagai berikut: (1) Setiap anggota memiliki peran, (2) terjadi hubungan interaksi langsung diantara siswa, (3) setiap anggota kelompok bertanggung jawab atas belajarnya dan juga teman-teman sekelompoknya, (4) guru membantu mengembangkan keterampilanketerampilan interpersonal kelompok, dan (5) guru hanya berinteraksi dengan kelompok saat diperlukan.

\section{Strategi Pembelajaran Kooperatif Tipe STAD}

Strategi pembelajaran koperatif tipe STAD merupakan pendekatan cooperative learning yang menekankan pada aktivitas dan interaksi di antara siswa untuk saling memotivasi dan saling membantu dalam menguasai materi pelajaran guna mencapai prestasi yang maksimal. Menurut Lie (2004:43) alasan perlunya kelompok heterogen dalam pembelajaran kooperatif : (1) kelompok heterogen memberikan kesempatan untuk saling mengajar (peer tutoring) dan saling mendukung. (2) kelompok ini meningkatkan relasi dan interaksi antara ras, agama, etnik dan gender. (3) kelompok heterogen memudahkan pengelolaan kelas karena adanya satu orang yang berkemampuan akademik tinggi, guru mendapatkan satu orang asisten untuk setiap tiga orang siswa.

Adapun kelebihan strategi pembelajaran kooperatif tipe STAD menurut Slavin ( 1995:17) yaitu: (1) siswa bekerjasama dalam mencapai tujuan dengan menjunjung tinggi norma-norma kelompok, (2) siswa aktif membantu dan memotivasi semangat untuk berhasil bersama, (3) aktif berperan sebagai tutor sebaya untuk lebih meningkatkan keberhasilan kelompok, (4) interaksi antar siswa seiring dengan peningkatan kemampuan mereka dalam berpendapat. Sedangkan kekurangan strategi pembelajaran kooperatif tipe STAD menurut Dess (1991:411) yaitu: (1) membutuhkan waktu yang lebih lama untuk siswa sehingga sulit mencapai target kurikulum, dan (2) membutuhkan waktu yang lebih lama untuk guru sehingga pada umumnya guru tidak mau menggunakan pembelajaran kooperatif, (3) membutuhkan kemampuan khusus guru sehingga tidak semua guru dapat melakukan pembelajaran kooperatif, (4) menuntut sifat tertentu dari siswa, misalnya sifat suka bekerjasma.

\section{Hakikat Strategi Pembelajaran Ekspositori}

Killen (1998:2) menamakan strategi ekspositori ini dengan istilah strategi pembelajaran langsung (direct insruction). Dalam sistem ini, guru menyajikan bahan dalam bentuk yang telah dipersiapkan secara rapih, sistematik dan lengkap sehingga siswa tinggal menyimak dan mencernanya secara teratur dan tertib. Siswa juga dituntut untuk menguasai bahan yang telah disampaikan tersebut. Sanjaya (2007:177) bahwa strategi pembelajaran ekspositori merupakan bentuk dari pendekatan pembelajaran yang berorientasikan kepada guru (teacher centered), sebab dalam strategi ini, guru memegang peran yang sangat dominan. Melalui strategi pembelajaran ini guru menyampaikan materi pelajaran secara terstruktur dengan harapan materi yang disampaikan dapat dikuasai oleh siswa dengan baik. Fokus utamanya adalah kemapuan akademik siswa.

Menurut Sanjaya (2008:83) dalam penggunaan strategi ekspositori terdapat beberapa prinsip yang harus diperhatikan oleh setiap guru yaitu; (1) Berorientasi Tujuan, walaupun penyampaian materi pembelajaran ciri utama dalam strategi pembelajaran ekspositori melalui metode ceramah tapi tidak berarti proses penyampaian materi tanpa tujuan pembelajaran, justru tujuan itulah yang menjadi pertimbangan utama dalam penggunaan strategi ini; (2) Prinsip Komunikasi, proses pembelajaran dapat dikatakan sebagai proses komunikasi, yang menunjukkan pada proses 
penyampaian pesan dari seseorang (sumber pesan) kepada seseorang atau sekelompok orang (penerima pesan), pesan ini adalah materi pembelajaran yang diorganisir dan disusun sesuai dengan tujuan tertentu yang ingin dicapai; (3) Prinsip Kesiapan. Dalam teori koneksionisme, "kesiapan" merupakan salah satu hukum belajar ini adalah bahwa setiap individu akan merespon setiap stimulus yang muncul manakala dalam dirinya belum memiliki kesiapan; (4) Prinsip Berkelanjutan, prinsip ekspositori harus dapat mendorong siswa untuk mau mempelajari pelajaran lebih lanjut. Pembelajaran ini bukan hanya berlangsung pada saat itu saja tetapi pada waktu selanjutnya.

Strategi pembelajaran ekspositori merupakan strategi pembelajaran yang banyak dan sering digunakan. Gulo (2002:84) menjelaskan strategi pembelajaran ekspositori memiliki kelebihan dan kelemahan. Kelebihan strategi ekspositori sebagai berikut: (1) guru mudah menguasai kelas; (2) mudah mempersiapkan dan melaksanakannya; (3) guru mudah menerangkan pelajaran dengan baik; (4) isi kurikulum dapat diselesaikan sesuai jadwal. Sedangkan kelemahannya adalah: pengetahuan yang diperoleh siswa mudah terlupakan; (2) tidak dapat melayani perbedaan setiap individu (perbedaan kemampuan, pengetahuan, minat, bakat dan sebagainya; (3) proses pembelajaran cenderung membosankan; (4) menyebabkan siswa pasif karena gaya komunikasi pembelajaran satu arah (one-way communication).

\section{Hakikat Tipe Kepribadian}

Masing-masing orang memiliki karakteristik kepribadian yang berbeda-beda yang mempengaruhi perilakunya. Kepribadian merupakan dasar dari seseorang bertingkah laku. Banyak ahli psikologi yang menjelaskan mengenai kepribadian. Cattel (dalam Suryabrata, 2003:298) mengemukakan kepribadian merupakan jalan untuk memprediksikan apa yang akan dilakukan seseorang pada situasi yang biasanya. Kepribadian merupakan persoalan mengenai segala aktivitas individu, baik yang tampak maupun tidak tampak. Sedangkan Atkinson \& Hilgard (1991:145) mengemukakan bahwa kepribadian merupakan pola perilaku dan cara berfikir yang khas, menentukan penyesuaian diri seseorang terhadap lingkungannya.
Eysenck (dalam Suryabrata, 2003:291) berpendapat bahwa kepribadian tersusun atas tindakan-tindakan, disposisi-disposisi yang terorganisasi dalam susunan hierarkis berdasarkan atas keumuman dan kepentingannya. Diurut dari yang paling tinggi dan paling mencakup ke paling rendah dan paling umum, serta isinya masing-masing adalah sebagai berikut :

1. Type, merupakan gambaran dari adanya suatu organisasi dalam diri individu dan menunjukkan adanya sistem saling berkaitan antara trait yang ada pada individu tersebut.

2. Trait, merupakan habitual response yang saling berhubungan satu dengan yang lainnya dan cenderung ada pada individu tertentu pula. Traits sering disebut juga an observed constellation of individual action tendencies atau suatu yang cenderung tetap terlihat sebagai hal yang melatarbelakangi suatu tingkah laku.

3. habitual response, merupakan corak respon yang sifatnya lebih umum dari spesific response, yaitu respon-respon yang berulang-ulang terjadi jika individu menghadapi kondisi atau situasi yang sama.

4. spesific response, merupakan tingkatan yang paling rendah. Disini tingkah laku individu belum menunjukkan karakter, respon yang diperlihatkan khusus sekali karena terjadi pada suatu keadaan atau kejadian tertentu.

Istilah ekstrovert dan introvert dipakai pertama kali oleh Jung. Menurut Jung, ekstrovert adalah orang yang pandangannya objektif dan tidak pribadi. Jung mengatakan ekstrovert adalah kepribadian yang lebih diperngaruhi oleh dunia objektif, orientasinya terutama tertuju ke luar, pikiran, perasaan, serta tindakannya lebih banyak ditentukan oleh lingkungan. Kemudian introvert adalah orang yang pandangannya subjektif dan individualis. Jadi, dapat dikatakan bahwa introvert adalah kepribadian yang lebih dipengaruhi oleh dunia subjektif, orientasinya tertuju ke dalam.

\section{Tipe Kepribadian Ekstrovert}

Eysenck (dalam Suryabrata, 2003:293) mengemukakan gambaran sifat tipe kepribadian ekstrovert adalah sebagai orang yang ramah dalam pergaulan, banyak teman, sangat memerlukan kegembiraan, ceroboh, impulsif. Secara lebih rinci dijabarkan dengan mudah 
marah, gelisah, agersif, mudah menerima rangsanng. berubah-ubah, impulsive, aktif, optimis, suka bergaul, ramah, banyak bicara, mau mendengar, menggampangkan, lincah, riang, kepemimpinan.

Adapun yang menjadi ciri-ciri individu ekstrovert: (1) bersikap positif terhadap masyarakat, sifat ini menunjukkan bahwa masyarakat merupkan tempat yang tepat untuk berinteraks, (2) hatinya terbuka artinya terbuka terhadap hal-hal baru tanpa adanya rasa canggung, (3) mudah bergaul artinya dapat dengan mudah berinteraksi dengan orang lain, (4) menarik perhatian, (5) bergantung terhadap kelompok, (6) tidak teliti artinya terburu-buru tanpa pemikiran yang matang, (7) mudah berubah adalah sifat mudah merubah suatu kesendirian karena pengaruh dari luar, dan (8) agresif artinya cepat mengambil tindakan dalam suatu permasalahan. (Suryabrata, 2007:162).

\section{Tipe Kepribadian Introvert}

Ciri-ciri individu introvert : (1) pendiam artinya tidak suka bicara, (2) menarik diri adalah sifat yang dimiliki seorang introverts yang selalu ingin menyendiri dan kurang menyukai keramaian, (3) penakut, (4) menahan diri dari suatu keinginan, (5) puas dengan dirinya sendiri, (6) kaku adalah sifat kurang fleksibel terhadap suatu yang baru dikenalnya karena kurang banyak mengenal dunia luar, (7) bijaksana adalah sifat tepat dalam mengambil keputusan yang diambilnya, dan (8) teliti adalah mengerjakan sesuatu dengan sepenuhnya untuk mendapatkan hasil yang sempurna (Suryabrata, 2007:162).

Rumusan masalah yang akan ditelusuri dalam penelitian ini adalah sebagai berikut: (1) Apakah ada perbedaan hasil belajar Ekonomi siswa yang dibelajarkan dengan strategi pembelajaran kooperatif tipe STAD dengan hasil belajar Ekonomi siswa yang diajar dengan strategi pembelajaran ekspositori?; (2) Apakah ada perbedaan hasil belajar Ekonomi antara siswa yang memiliki tipe kepribadian ekstovert dengan hasil belajar Ekonomi siswa yang memiliki tipe kepribadian introvert?; dan (3) Apakah ada interaksi antara strategi pembelajaran dan tipe kepribadian terhadap hasil belajar Ekonomi?

\section{METODE}

Penelitian ini akan dilaksanakan di SMA Negeri 1 Siantar Kabupaten Simalungun. Populasi dalam penelitian ini adalah seluruh siswa Kelas X SMA Negeri 1 Siantar Kabupaten Simalungun, berjumlah 234 orang yang terdiri dari enam kelas paralel yaitu kelas $\mathrm{X}_{1}, \mathrm{X}_{2}, \mathrm{X}_{3}, \mathrm{X}_{4}, \mathrm{X}_{5}, \mathrm{X}_{6}$, Karakteristik siswa SMA Negeri 1 Siantar Kabupaten Simalungun yang tersebar dalam 6 kelas diasumsikan memiliki karakteristik yang sama. Teknik penentuan sampel digunakan cluster random sampling. Dari 6 kelas diperoleh 2 kelas terpilih sebagai sampel penelitian, selanjutnya kelas X1 terpilih sebagai kelas yang akan diberi perlakuan dengan strategi pembelajaran kooperatif tipe STAD dengan jumlah 40 siswa, sedangkan kelas X4 dengan jumlah 38 siswa terpilih sebagai kelas yang diberi perlakuan dengan strategi pembelajaran ekspositori.

Metode penelitian yang digunakan adalah metode kuasi eksperimental semu (quasi experimental research). Perlakuan dilaksanakan pada pembelajaran ekonomi dengan menggunakan strategi pembelajaran kooperatif tipe STAD di kelas yang dibandingkan dengan strategi ekspositori yang dilaksanakan pada kelas kontrol.

Pada masing-masing kelas diberikan tes tipe kepribadian sebelum perlakuan untuk mengetahui tipe kepribadian yang dimiliki siswa. Tipe kepribadian terdiri dari tipe kepribadian ekstrovert dan introvert. Guru yang telah ditetapkan untuk melakukan pembelajaran dengan strategi pembelajaran kooperatif tipe STAD maupun ekspositori diberikan petunjuk cara menyajikan materi pelajaran.

Desain penelitian menggunakan faktorial $2 \times 2$. Adapun desain penelitian dapat dilihat pada Tabel 1 berikut

Tabel 1. Desain Penelitian Faktorial 2x2

\begin{tabular}{|c|c|c|}
\hline Strategi Pembelajaran (A) & STAD $\left(\mathrm{A}_{1}\right)$ & Ekspositori $\left(\mathrm{A}_{2}\right)$ \\
\hline Tipe Kepribadian $(\mathrm{B})$ & $\mathrm{A}_{1} \mathrm{~B}_{1}$ & $\mathrm{~A}_{2} \mathrm{~B}_{1}$ \\
\hline Ekstrovert $\left(\mathrm{B}_{1}\right)$ & $\mathrm{A}_{1} \mathrm{~B}_{2}$ & $\mathrm{~A}_{2} \mathrm{~B}_{2}$ \\
\hline Introvert $\left(\mathrm{B}_{2}\right)$ & & \\
\hline
\end{tabular}


Keterangan :

A $=$ Strategi Pembelajaran

$\mathrm{B}=$ Tipe Kepribadian

$A_{1}=$ Strategi pembelajaran kooperatif tipe STAD

$\mathrm{A}_{2} \quad=$ Strategi pembelajaran ekspositori

$\mathrm{B}_{1}=$ Kepribadian Ekstrovert

$\mathrm{B}_{2}=$ Kepribadian Introvert

$\mathrm{A}_{1} \mathrm{~B}_{1}=$ Hasil belajar Ekonomi siswa yang dibelajarkan dengan strategi pembelajaran kooperatif tipe STAD pada siswa dengan kepribadian ekstrovert

$A_{1} B_{2}=$ Hasil belajar Ekonomi siswa yang dibelajarkan dengan strategi pembelajaran kooperatif tipe STAD pada siswa dengan kepribadian introvert

$\mathrm{A}_{2} \mathrm{~B}_{1}=$ Hasil belajar Ekonomi siswa yang dibelajarkan dengan strategi pembelajaran ekspositori pada siswa dengan kepribadian ekstrovert

$\mathrm{A}_{2} \mathrm{~B}_{2}=$ Hasil belajar Ekonomi siswa yang dibelajarkan dengan strategi pembelajaran ekspositori pada siswa dengan kepribadian introvert

Teknis analisis data yang digunakan berupa analisis deskriptif dan analisis inferensial. Teknik analisis deskriptif dimaksudkan untuk mendeskripsikan data penelitian meliputi mean, median, standar deviasi dan kecenderungan data. Data-data yang diperoleh selanjutnya disajikan dalam bentuk tabel distribusi frekuensi dan histogram. Teknik analisis inferensial digunakan untuk menguji hipotesis penelitian dengan menggunakan teknik analisis varians (ANAVA) dua jalur.

Terlebih dahulu dilakukan uji persyaratan analisis yaitu uji normalitas dan homogenitas data. Uji persyaratan normalitas untuk mengetahui apakah data yang diteliti berdistribusi normal atau tidak. Uji normalitas dilakukan dengan menggunakan uji statistic Liliefors. Kriteria yang digunakan data berdistribusi normal jika $L_{\text {hitung }}<L_{\text {tabel }}$ pada taraf signifikansi $5 \%$. Uji homogenitas variabel dilakukan dengan uji Fisher dan uji Barlett untuk melihat apakah data diperoleh melalui varians yang homogen atau tidak dengan kriteria bahwa data memiliki varians homogen jika perbandingan nilai probabilitas hitung lebih kecil dari nilai tabel pada taraf signifikansi $5 \%$.

Setelah dilakukan pengujian persyaratan analisis maka dilanjutkan pengujian hipotesis dengan teknik analisis varians untuk tiap variabel beserta interaksinya. Kriteria uji hipotensis dilakukan pada taraf signifikasi $5 \%$. Selanjutnya dilakukan uji lanjut dengan menggunakan uji Scheffe karena jumlah responden setiap kelompok berbeda (N berbeda). Selanjutnya untuk keperluan pengujian hipotesis, dirumuskan hipotesis statistik sebagai berikut:

Hipotesis Pertama

Ho : $\mu A_{1}=\mu A_{2}$

$\mathrm{Ha}: \mu \mathrm{A}_{1}>\mu \mathrm{A}_{2}$

Hipotesis Kedua

Ho : $\mu \mathrm{B}_{1}=\mu \mathrm{B}_{2}$

$\mathrm{Ha}: \mu \mathrm{B}_{1}>\mu \mathrm{B}_{2}$

Hipotesis Ketiga

Ho: $\mathrm{A}><\mathrm{B}=0$

$\mathrm{Ha}: \mathrm{A}><\mathrm{B} \neq 0$

Keterangan:

$\mu \mathrm{A}_{1} \quad$ : Rata-rata hasil belajar ekonomi yang diperoleh dengan strategis pembelajaran kooperatif tipe STAD

$\mu \mathrm{A}_{2} \quad$ : Rata-rata hasil belajar ekonomi yang diperoleh dengan pembelajaran ekspositori

$\mu \mathrm{B}_{1}$ : Rata-rata hasil belajar ekonomi siswa yang memiliki tipe kepribadian ekstrovert

$\mu B_{2} \quad$ : Rata-rata hasil belajar ekonomi siswa yang memiliki tipe kepribadian introvert

A $><$ B : Interaksi antara strategi pembelajaran dengan tipe kepribadian

\section{HASIL DAN PEMBAHASAN}

Pengujian hipotesis pertama, kedua dan ketiga dilakukan dengan menggunakan analisis varians faktorial $2 \times 2$. Berikut ini rangkuman perhitungannya: 
Tabel 2. Rangkuman Anava Faktorial 2x2

\begin{tabular}{|c|c|c|c|c|c|}
\hline Sumber Variasi & $\mathrm{JK}$ & $\mathrm{dK}$ & $\mathrm{RJK}$ & $\mathrm{Fh}$ & $\mathrm{Ft}(\alpha=0,05)(1,74)$ \\
\hline $\begin{array}{c}\text { Strategi } \\
\text { Pembelajaran (A) }\end{array}$ & 558,89 & 1 & 558,89 & 55,28 & 3,97 \\
\hline Tipe Kepribadia & 585,79 & 1 & 585,79 & 57,94 & 3,97 \\
\hline Interaksi (AB) & 72,22 & 1 & 72,22 & 7,14 & 3,97 \\
\hline Galat & 748,45 & 74 & 10,11 & & - \\
\hline Total & 1965,35 & 77 & - & - & - \\
\hline
\end{tabular}

Pengujian hipotesis pertama yang berbunyi: hasil belajar Ekonomi siswa yang dibelajarkan dengan strategi pembelajaran kooperatif tipe STAD lebih tinggi daripada hasil belajar Ekonomi siswa yang dibelajarkan dengan strategi pembelajaran ekspositori. Hipotesis statistiknya adalah:

$$
\begin{aligned}
& \text { Ho }: \mu_{A 1}=\mu_{A 2} \\
& \text { Ha }: \mu_{A 1}>\mu_{A 2}
\end{aligned}
$$

Berdasarkan analisis data diperoleh nilai rata-rata hasil belajar Ekonomi siswa yang dibelajarkan dengan strategi pembelajaran kooperatif tipe STAD sebesar 27,97, sedangkan rata-rata hasil belajar Ekonomi siswa yang dibelajarkan dengan strategi pembelajaran ekspositori sebesar 27,65.

Hasil perhitungan anava diperoleh $F_{\text {hitung }}=55,28$ sedangkan $F_{\text {tabel }}=3,97$ untuk $\mathrm{dk}(1,74)$ dan taraf nyata $\alpha=0,05$. Ternyata $F_{\text {hitung }}>F_{\text {tabel }} \quad(55,28>3,97), \quad$ sehingga pengujian hipotesis menolak Ho. Dengan demikian dapat disimpulkan bahwa hasil belajar Ekonomi siswa yang dibelajarkan dengan strategi pembelajaran kooperatif tipe STAD lebih tinggi dibandingkan dengan hasil belajar Ekonomi siswa yang dibelajarkan dengan strategi pembelajaran ekspositori dapat diterima dan terbukti secara empirik.

Pengujian hipotesis kedua yang berbunyi: hasil belajar Ekonomi siswa yang memiliki kepribadian tipe kepribadian ekstrovert lebih tinggi daripada hasil belajar Ekonomi siswa yang memiliki tipe kepribadian introvert. Hipotesis statistiknya adalah:

Ho : $\mu_{B 1}=\mu_{B 2}$
$\mathrm{Ha}: \mu_{B 1}>\mu_{B 2}$

Berdasarkan analisis data diperoleh nilai rata-rata hasil belajar Ekonomi siswa yang memiliki tipe kepribadian ekstrovert sebesar 28,75 , sedangkan rata-rata hasil belajar Ekonomi siswa yang memiliki tipe kepribadian introvert sebesar 27,14.

Hasil perhitungan anava diperoleh $F_{\text {hitung }}=57,94$ sedangkan $F_{\text {tabel }}=3,97$ untuk dk $(1,74)$ dan taraf nyata $\alpha=0,05$. Ternyata $F_{\text {hitung }}>F_{\text {tabel }} \quad(57,94>3,97), \quad$ sehingga pengujian hipotesis menolak Ho. Dengan demikian dapat disimpulkan bahwa hasil belajar Ekonomi siswa yang memiliki tipe kepribadian ekstrovert lebih tinggi dibandingkan dengan hasil belajar Ekonomi siswa yang memiliki tipe kepribadian introvert dapat diterima dan terbukti secara empirik.

Pengujian hipotesis ketiga yang berbunyi: terdapat interaksi antara strategi pembelajaran dan tipe kepribadian dalam mempengaruhi Hasil Belajar Ekonomi. Hipotesis statistiknya adalah:

Ho : $\mathrm{A}><\mathrm{B}=0$

$\mathrm{Ha}: \mathrm{A}><\mathrm{B} \neq 0$

Hasil perhitungan anava diperoleh $F_{\text {hitung }}=7,14$ sedangkan $F_{\text {tabel }}=3,97$ untuk dk $(1,74)$ dan taraf nyata $\alpha=0,05$. Ternyata $F_{\text {hitung }}>F_{\text {tabel }} \quad(7,14>3,97), \quad$ sehingga pengujian hipotesis menolak Ho. Dengan demikian dapat disimpulkan bahwa terdapat interaksi antara strategi pembelajaran kooperatif tipe STAD dan tipe kepribadian dalam mempengaruhi hasil belajar Ekonomi dapat diterima dan terbukti secara empirik. 


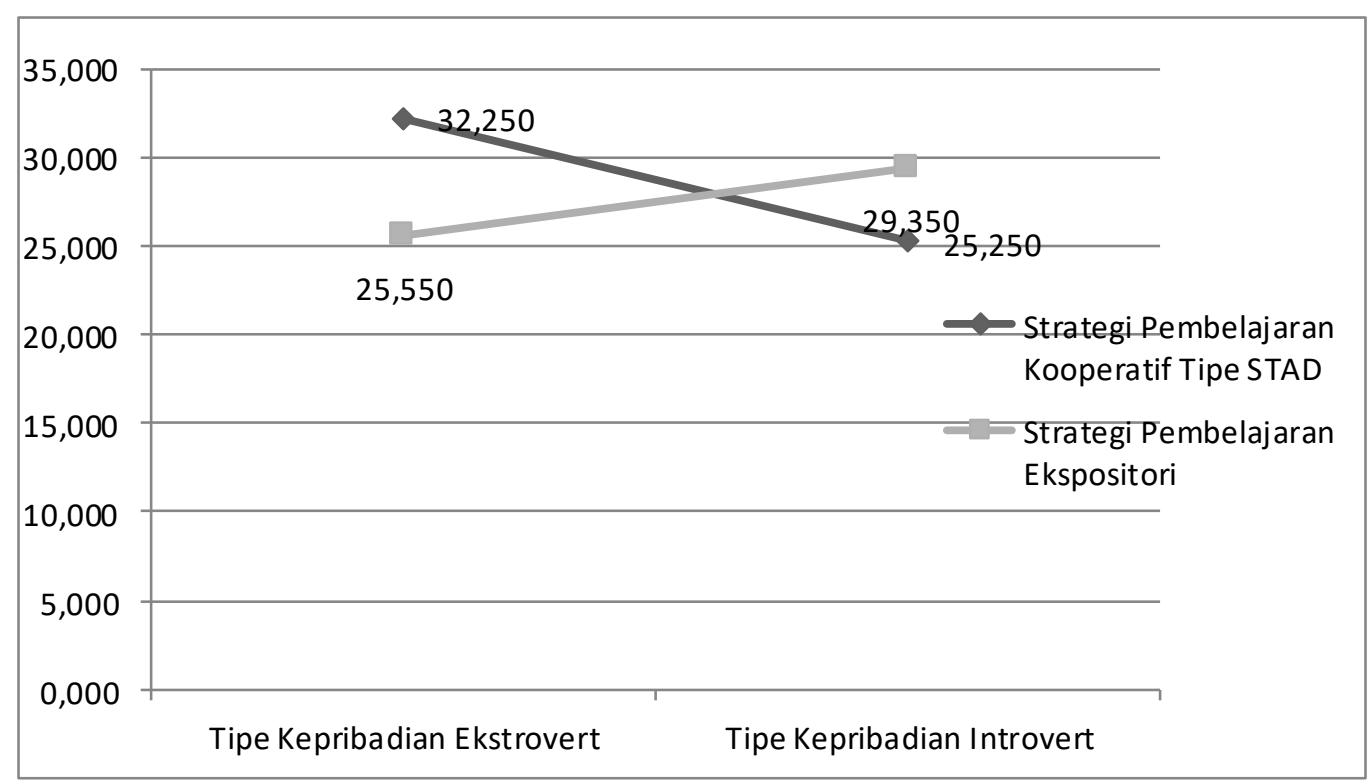

Gambar 1. Interaksi Strategi Pembelajaran dan Tipe Kepribadian

Dari gambar di atas dapat dilihat bahwa antara garis pembelajaran dengan strategi pembelajaran kooperatif tipe STAD membentuk interaksi antara pembelajaran dengan strategi ekspositori. Dari grafik di atas menunjukkan bahwa siswa yang memiliki tipe kepribadian ekstrovert lebih cocok dibelajarkan dengan strategi pembelajaran kooperatif tipe STAD sedangkan siswa yang memiliki tipe kepribadian introvert lebih cocok dibelajarkan dengan strategi pembelajaran ekspsitori. Karena jumlah $\mathrm{N}$ pada setiap kelompok yang diteliti tidak sama, maka dilakukan uji lanjut dengan uji Scheffe.

Untuk mengetahui interaksi antara strategi pembelajaran dan tipe kepribadian terhadap hasil belajar Ekonomi, maka dilakukan uji lanjut dengan uji Scheffe karena jumlah $\mathrm{N}$ berbeda. Rangkuman uji Scheffe dapat dilihat pada tabel berikut ini:

Tabel 3. Rangkuman Uji Scheffe

\begin{tabular}{|l|c|c|c|}
\hline \multicolumn{2}{|c|}{ Hipotesis Statistik } & $F_{\text {hitung }}$ & $F_{\text {tabel }(3,74)}(\alpha=0,05)$ \\
\hline Ho $: \mu_{11}=\mu_{12}$ & $\mathrm{Ha}: \mu_{11}>\mu_{12}$ & 6,38 & 2,73 \\
\hline Ho $: \mu_{11}=\mu_{21}$ & $\mathrm{Ha}: \mu_{11}>\mu_{21}$ & 6,93 & 2,73 \\
\hline Ho $: \mu_{11}=\mu_{22}$ & $\mathrm{Ha}: \mu_{11}>\mu_{12}$ & 2,76 & 2,73 \\
\hline Ho $: \mu_{12}=\mu_{21}$ & $\mathrm{Ha}: \mu_{12}>\mu_{21}$ & 0,31 & 2,73 \\
\hline Ho $: \mu_{12}=\mu_{22}$ & $\mathrm{Ha}: \mu_{12}>\mu_{22}$ & $-3,80$ & 2,73 \\
\hline Ho $: \mu_{21}=\mu_{22}$ & $\mathrm{Ha}: \mu_{21}>\mu_{22}$ & $-4,31$ & 2,73 \\
\hline
\end{tabular}

Keterangan:

$\mu_{11}=$ Hasil belajar ekonomi siswa yang dibelajarkan dengan strategi pembelajaran kooperatif tipe STAD dantipe kepribadian ekstrovert.

$\mu_{12}=$ Hasil belajar ekonomi siswa yang dibelajarkan dengan strategi pembelajaran ekspositori dan tipe kepribadian ekstrovert.

$\mu_{21}=$ Hasil belajar ekonomi siswa yang dibelajarkan dengan strategi pembelajaran Kooperatif Tipe STAD dan tipe kepribadian introvert.

$\mu_{22}=$ Hasil belajar ekonomi siswa yang dibelajarkan dengan strategi pembelajaran ekspositori dantipe kepribadian introvert.

1. Perbandingan kelompok $\mu_{11}$ dengan $\mu_{12}$ diperoleh $\quad F_{\text {hitung }}>\quad F_{\text {tabelsehingga }}$ memberikan keputusan menerima Ha. Dengan demikian, hipotesis yang menyatakan bahwarata-rata hasil belajar ekonomisiswa yang dibelajarkan dengan 
strategi pembelajaran kooperatif tipe STADdan tipe kepribadian ekstrovert lebih tinggi daripadarata-rata hasil belajar ekonomi yang dibelajarkan dengan strategi pembelajaran ekspositoridan tipe kepribadian ekstrovert, teruji kebenarannya.

2. Perbandingan kelompok $\mu_{11}$ dengan $\mu_{21}$ diperoleh $\quad F_{\text {hitung }}>\quad F_{\text {tabelsehingga }}$ memberikan keputusan menerima Ha. Dengan demikian, hipotesis yang menyatakan bahwa rata-rata hasil belajar ekonomisiswa yang dibelajarkan dengan strategi pembelajaran kooperatif tipe STAD dan tipe kepribadian ekstrovert lebih tinggi daripada rata-rata hasil belajar ekonomi siswa yang dibelajarkan dengan strategi pembelajaran kooperatif tipe STAD dan tipe kepribadianintrovert, teruji kebenarannya.

3. Perbandingan kelompok $\mu_{11}$ dengan $\mu_{22}$ diperoleh $\quad \mathrm{F}_{\text {hitung }}>\quad \mathrm{F}_{\text {tabel }}$ sehingga memberikan keputusan menerima Ha. Dengan demikian, hipotesis yang menyatakan bahwa rata-rata hasil belajar ekonomisiswa yang dibelajarkan dengan strategi pembelajaran kooperatif tipe STAD dan tipe kepribadianekstrovert lebih tinggi daripada rata-rata hasil belajar ekonomi siswa yang dibelajarkan dengan strategi pembelajaran ekspositoridan tipe kepribadian introvert, teruji kebenarannya.

4. Perbandingan kelompok $\mu_{12}$ dengan $\mu_{21}$ diperoleh $\quad \mathrm{F}_{\text {hitung }}<\quad \mathrm{F}_{\text {tabel }}$ sehingga memberikan keputusan menolak Ha. Dengan demikian, hipotesis yang menyatakan bahwa rata-rata hasil belajar ekonomi siswa yang dibelajarkan dengan strategi pembelajaran ekspositori dan tipe kepribadian ekstrovert tidak berbeda signifikan dengan rata-rata hasil belajar ekonomi siswa yang dibelajarkan dengan strategi pembelajaran kooperatif tipe STAD dan tipe kepribadian introvert tidak teruji kebenarannya.

5. Perbandingan kelompok $\mu_{12}$ dengan $\mu_{22}$ diperoleh $\quad \mathrm{F}_{\text {hitung }}<\quad \mathrm{F}_{\text {tabel }}$ sehingga memberikan keputusan menolak Ha. Dengan demikian, hipotesis yang menyatakan bahwa rata-rata hasil belajar ekonomisiswa yang dibelajarkan dengan strategi pembelajaran ekspositori dan tipe kepribadian ekstroverttidak berbeda signifikan daripada rata-rata hasil belajar ekonomisiswa yang dibelajarkan dengan strategi pembelajaran ekspositoridan tipe kepribadian introvert, tidak teruji kebenarannya.

6. Perbandingan kelompok $\mu_{21}$ dengan $\mu_{22}$ diperoleh $\quad F_{\text {hitung }}<\quad F_{\text {tabel }}$ sehingga memberikan keputusan menolak Ha. Dengan demikian, hipotesis yang menyatakan bahwarata-rata hasil belajar ekonomi siswa yang dibelajarkan dengan strategi pembelajaran kooperatif tipe STAD dantipe kepribadian introverttidak berbeda signifikan daripada rata-rata hasil belajar ekonomi siswa yang dibelajarkan dengan strategi pembelajaran ekspositori dan tipe kepribadian introvert, tidak teruji kebenarannya.

\section{Pembahasan}

Sebagaimana dijelaskan Slavin (1995:71) pembelajaran kooperatif merupakan suatu pembelajaran dengan penekanan pada aspek sosial dengan menggunakan kelompokkelompok kecil yang terdiri dari 4-5 siswa yang sederajat tetapi heterogen untuk menghasilkan pemikiran dan tantangan miskonsepsi siswa sebagai unsur kuncinya.Strategi pembelajaran koperatif tipe STAD merupakan pendekatan cooperative learning yang menekankan pada aktivitas dan interaksi di antara siswa untuk saling memotivasi dan saling membantu dalam menguasai materi pelajaran guna mencapai prestasi yang maksimal.

Ruang lingkup dari mata pelajaran Ekonomi meliputi aspek-aspek:

Perekonomian; (2) Ketergantungan;

Perkoperasian; (5) Kewirausahaan; dan (6) Akuntansi dan Manajemen. Keseluruh aspekaspek tersebut diselenggarakan dalam proses belajar mengajar agar siswa dapat merekam peristiwa ekonomi yang terjadi disekitar lingkungannya dan mengambil manfaat untuk kehidupannya yang lebih baik.Dengan demikian, untuk dapat memahami materi Ekonomi dibutuhkan strategi pembelajaran kooperatif tipe STAD sehingga siswa dapat bersama-sama mendiskusikan peristiwa ekonomi secara berkelompok. Sedangkan dengan menggunakan strategi pembelajaran ekspositori, mata pelajaran Ekonomi akan lebih sulit dipahami oleh siswa karena dalam proses pembelajaran yang berpusat pada guru dan berbentuk ceramah sehingga siswa kurang dilibatkan untuk mengekspresikan pengalaman belajarnya dalam kehidupan sehari-hari sebagai 
makhluk ekonomidan berdampak pada kejenuhanbelajar bagi siswa.

Temuan menunjukkan hasil belajar Ekonomi siswa dengan tipe kepribadian ekstrovert secara keseluruhan baik yang dibelajarkan dengan strategi pembelajaran kooperatif tipe STAD dan strategi pembelajaran ekspositori lebih tinggi daripada rata-rata hasil belajar Ekonomi siswa dengan tipe kepribadian introvert. Hal ini dapat terjadi karena dalam pembelajaran Ekonomi, siswa yang memiliki kepribadian ekstrovertindividu yang mudah bergaul, cepat tanggap dalam memberikan jawaban atas pertanyaan yang dilontarkan kepadanya, memiliki lebih banyak kontak sosial dan frekuensi untuk bergabung dalam aktifitas kelompok, mudah bersosialisasi untuk mempelajari dan memecahkan permasalahanpermasalahan yang terjadi disekitar kehidupan manusia sebagai makhluk ekonomi yang membutuhkan keterlibatan aktivitas kelompok. Sedangkan siswa dengan tipe kepribadian introvert merupakan tipe kepribadian yang orientasi jiwanya terarah ke dalam dirinya, suka menyendiri,menjaga jarak terhadap orang lain, cenderung pemalu, membutuhkan waktu agak lama dalam penyesuaian diri terhadap lingkungan, agak pesimis serta jarang berperilaku agresif sehingga dalam aktivitas belajar di kelas cenderung pasif.

Hasil pengujian hipotesis menunjukkan keseluruhan hipotesis penelitan yaitu: (1) hasil belajar Ekonomi siswa yang dibelajarkan dengan strategi pembelajaran kooperatif tipe STAD lebih tinggi daripada hasil belajar Ekonomi siswa yang dibelajarkan dengan strategi pembelajaran ekspositori, (2) hasil belajar Ekonomi siswadengan tipe kepribadian ekstrovert lebih tinggi daripada hasil belajar Ekonomi siswa dengan tipe kepribadian introvert, dan (3) terdapat interaksi strategi pembelajaran dan tipe kepribadian dalam memberikan pengaruh terhadap hasil belajar Ekonomi siswa, dapat diterima.

Memperhatikan cakupan dan kedalaman mata pelajaran Ekonomi, maka dibutuhkan suatu strategi yang mampu mendeskripsikan secara rinci, mendefinisikan dan memahami konsep-konsep, memahami teori-teori dan mampu mengevaluasi dan melakukan keterampilan dalam pembelajaran yang efektif dan efisien.Dengan demikian siswa diharapkan mampu membangun atau mengkonstruk sendiri pengetahuan dan keterampilan yang dibutuhkan untuk memahami materi ajar Ekonomi. Di samping itu, penerapan strategi pembelajaran kooperatif tipe STAD, strategi pembelajaran ekspositori maupun strategi pembelajaran yang lainnya diharapkan siswa dapat mengembangkan dan menggunakan gagasan-gagasan dalam menyelesaikan masalah pembelajaran, sehingga pengetahuan dan keterampilan akan dapat dingat dan dipahami dalam memori jangka panjang, dan sewaktu-waktu dapat digunakan sesuai dengan kebutuhan belajar siswa.

Dari hasil penelitian ini dapat dikatakan bahwa strategi pembelajaran disesuaikan dengan karakteristik siswa yakni tipe kepribadian dan materi pelajaran yang disampaikan.Ini dilakukan agar pelajaran yang disampaikan dapat menarik perhatian siswa dan tidak membosankan. Apabila guru memperhatikan karakteristik siswa, maka besar kemungkinan guru dapat memilih strategi pembelajaran yang tepat, sehingga siswa akan memperoleh hasil belajar Ekonomi yang lebih maksimal.

\section{PENUTUP}

Simpulan-simpulan yang dapat ditarik dari hasil penelitian adalah sebagai berikut:

1. Adanya perbedaan hasil belajar Ekonomi siswa yang dibelajarkan dengan strategi pembelajaran kooperatif tipe STAD dengan rata-rata hasil belajar Ekonomi siswa yang lebih tinggi daripada rata-rata hasil belajar siswa yang dibelajarkan dengan strategi pembelajaran ekspositori. Dengan demikian strategi pembelajaran lebih efektif diterapkan dalam pembelajaran Ekonomi guna meningkatkan hasil belajar siswa.

2. Adanya perbedaan hasil belajar Ekonomi siswa yang memiliki tipe kepribadian ekstrovert dengan rata-rata hasil belajar yang lebih tinggi dibandingkan dengan rata-rata hasil belajar Ekonomi siswa yang memiliki tipe kepribadian introvert.

3. Terdapat interaksi antara strategi pembelajaran dan tipe kepribadian siswa. Untuk siswa yang memiliki tipe kepribadian ekstrovert akan lebih efektif dalam meningkatkan hasil belajar Ekonomi siswa jika menggunakan strategi pembelajaran kooperatif tipe STAD, sedangkan untuk siswa yang memiliki tipe kepribadian introvert, strategi pembelajaran ekspositori lebih efektif dalam meningkatkan hasil belajar Ekonomi siswa dibandingkan jika 
menggunakan strategi pembelajaran kooperatif tipe STAD.

\section{DAFTAR PUSTAKA}

Atkinson, R.L. \& Hilgard. (1991). Pengantar Psikologi. (Alih bahasa: Dra. Nurdjanah Taufiq Dra. Rukmini Barhana). Jakarta: PT. Gelora Aksara Pratama

Bloom, B.S. (1976). Human Characteristics and School Learning. New York: McGraw-Hill Company

Departemen Pendidikan Nasional. (2006). Standar Kompetensi Mata Pelajaran Ekonomi. Jakarta: Departemen Pendidikan Nasional

Dess, R.L. (1991). The Role of Cooperative Learning in Increasing Problem Solving Ability in a College Remedial Course. Journal for Research in Mathematics Education

Dick, W., \& Carey, L. (2015). The Systematic Design of Instruction. Six edition. United State of Amerika: Pearson

Dimyati \& Moedjiono. (2002). Belajar dan Perkembangan. Jakarta : PT. Rineka Cipta

Gagne, R.M., \& Briggs. L.J. (1979). Principles of Instructional Design. New York: Holt Rinehart and Winston

Gagne, R.M. (1985). The Conditions of Learning and Theory of Instruction. New York: Holt, Rinehart and Winston Company

Gerlach, V.S., \& Ely, D.P. (1980). Teaching and Media A Systematic Approach. New Jersey: Prentice Hall Inc

Gulo, W. 2002. Strategi dan Pembelajaran. Jakarta:Grasindo

Hamalik, O. (2003). Kurikulum dan Pembelajaran. Jakarta: Bumi Aksara

Hamalik, O. (2006). Proses Belajar Mengajar. Bandung: Bumi Aksara

Isjoni. (2009). Cooperative Learning. Bandung: ALFABETA

Johnson \& Johnson. 2001. Psikologi Kelompok. Jakarta : Balai Pustaka

Kagan, R.H. (2000). Action in Elementary School: An Introduction. USA: John Hopkins University Press

Kauchak. (1998). Learning and Teaching: Riset and Based Method. Amerika Serikat: Aviacom Company
Kemp, J.E. (1994). Designing Effective Instruction. New York: Mic Millan Publisher

Kemp, J.E. (1995). Planing, Producing and Using Instructional Technologies. New York: Harper Collins

Killen, R. (1998). Effective Teaching Strategies: Lesson From Research and Practice, second edition. Australia: Social Science Press

Lie, A. (2004). Cooperative Learning: Mempraktekkan Cooperative Learning di Ruang-Ruang Kelas. Jakarta: PT. Grasindo

Lie, A. (2008). Kooperatif Learning. Jakarta: PT. Rajagrafindo

Poedjiadi, A. (2005). Sains Teknologi Masyarakat; Model Pembelajaran Kontekstual Bermuatan Nilai. Bandung: Remaja Rosdakarya

Reigeluth, C.M. (1983). Instructional Design Theories and Models An Overview of Their Current Status. New Jersey: Lawrence Erlbaum Associates Publisher

Romizowski, A.J. (1981). Design Instructional System. London: Kogan

Rustaman, et, al. (2003). Common Text Book Strategi Belajar mengajar Biologi. (Edisi Revisi). Bandung: JICA-IMSTEP-UPI

Sanjaya, W. (2007). Strategi Pembelajaran Beorientasi Standar Proses Pendidikan. Jakarta: Kencana Prenada Media Group

Sanjaya, W. (2008). Strategi Pembelajaran Berorientasi Standar Proses Pendidikan. Jakarta: Kencana Prenada Media Group

Siregar, E \& Nara, H. (2010). Teori Belajar dan Pembelajaran. Bogor: Ghalia Indonesia

Slameto. 2003. Belajar dan Faktor-Faktor yang Mempengaruhinya. Jakarta: Rineka Cipta

Slavin, R.E. (1995). Cooperative Learning: Theory, Research, and Practice, (seconded). Boston: Allyn and Bacon

Slavin, R.E. (2005). Cooperative Learning: Teori, Riset, dan Praktik. Bandung: Nusa Media

Suparman, A. (2001). Desain Instruksional. Jakarta: Pau Dirjen Dikti Depdikbud

Suryabrata, S. 2002. Psikologi Pendidikan. Jakarta: Raja Grafindo Persada

Suryabrata, S. (2003). Pengembangan Alat Ukur Psikologi. Yogyakarta: Penerbit Andi

Suryabrata, S. (2007). Psikologi Kepribadian. Jakarta: Raja Grafindo Persada 